\title{
Strength and riches: Nicholas Barbon's new politics of commerce
}

\author{
GEOFFREY C. KELLOW \\ Carleton University
}

\begin{abstract}
Nicholas Barbon's A discourse of trade presents, in its construction, substance, and rhetoric, an early outline of a new science of the legislator for the new politics of commerce. Barbon drew together economic and political arguments, applying insights from the latter to a new understanding of the political potential of the former. His accounts of the aspect of infinity in economic growth, his attack on analogical theorizing, and his endorsement of prodigality all served a larger political purpose. While he is primarily remembered for these individual economic contributions, it is the larger project, the envisioning of a new politics of commerce and commercial empires that marks out his A discourse of trade as groundbreaking. Almost a century before Adam Smith's famous definition of economics as a branch in the larger science of the legislator, Barbon offered an early account of the vital connection between economic thought, political philosophy, and statecraft.
\end{abstract}

Keywords: Nicholas Barbon, Machiavelli, balance of trade, commercial empire

JEL Classification: A11, B11, B31

Nicholas Barbon (ca. 1640-1699) had good reason to avoid politics. As the son of Praise-God Barbon (1596-1679) the long-imprisoned namesake of the 'Barebones' parliament, Nicholas keenly understood the personal perils of public life. Living through the Wars of the Three Kingdoms, the Restoration, the Succession Crisis and ultimately the Glorious Revolution, Barbon experienced political life as a series of challenges, obstacles and opportunities to cope with, accommodate, and adjust to. Barbon managed by turning to trade. Trained at Leyden as a physician, he quickly adjusted his ambitions, turning from medicine to trade upon returning to England. He made his fortune first as a builder

AUTHOR's NotE: I am grateful for comments, insights, and suggestions on earlier versions of this text provided by Kelly L. Walker, Michael Bird, and the two anonymous referees. 
in the aftermath of the Great Fire of London. Later, Barbon organized England's first fire insurance plan. Indeed, it is perhaps because Barbon was so intellectually, professionally, and personally adept at coping with challenge and change that his contributions to political and economic thought stand diminished today. His ideas concerning the relationship between commerce and politics were never fully detached from his own attempts to cope with the constant flux of seventeenth century English politics.

Admittedly, Barbon's early pamphlets, including "An apology for the builder; or a discourse shewing the cause and effects of the increase of building" (1859 [1685]), were little more than special pleadings for particular causes in which he was quite literally invested. Even his later, more substantial works, A discourse of trade (1905 [1690]) and A discourse concerning the coining of new money lighter: in answer to Mr. Lock's [sic] considerations about raising the value of money (1971 [1696]) contain transparently self-interested arguments. Unlike Machiavelli, who began The prince (1998 [1532]) with an explicit appeal to the Medici, Barbon's apparent self-interest, surely informed by the uncertainty of his times, profoundly diminished his standing in the history of political thought. ${ }^{1}$

Most modern evaluations of Nicholas Barbon tend to pry out of his larger arguments those elements that presaged future economic ideas. Today Barbon is remembered for his contributions to theories of currency, consumption and as an early analyst of what would much later become known as the Veblen effect (Barbon 1905 [1690], 34; Ullmer 2007, 110). These modern assessments of Barbon share a critical shortcoming, a failing that further explains his diminished status. They all fail to connect Barbon's economic insights to his political concerns. Indeed, in a poignant irony that is all too common in modern economic

\footnotetext{
${ }^{1}$ In terms of the simple availability of Barbon's $A$ discourse of trade, its recent inclusion in Henry C. Clark's excellent collection Commerce, culture, and liberty (2003) represents at least a partial remedy. In the modern scholarly treatment of Barbon a number of authors have treated economic aspects of Barbon's argument, most notably Schumpeter's History of economic analysis (1954), and Vickers's Studies in the theory of money, 1690-1776 (1959). More recently still, a number of scholars have considered Barbon's A discourse of trade against a larger backdrop of political, cultural, and ideological change, noteworthy among these are Christopher Berry's The idea of luxury (1994), and Joyce Appleby's Economic thought and ideology in seventeenth century England (1978).
} 
readings of the early texts of political economy, Barbon's writing succumbed to the intellectual and disciplinary parochialism it explicitly cautions against. In the preface to A discourse of trade, Barbon warned against this modern propensity to consider commercial questions outside of their larger economic, social and political context. Barbon believed that these intellectual blinders, worn most prominently by the rising merchant class, threatened the political and economic order that facilitated their rise in the first place.

The Merchant, and other Traders who should understand the true interest of TRADE, do either not understand it, or else, lest it might hinder their private Gain, will not Discover it (Barbon 1905 [1690], 7).

Barbon was among the first to recognize the propensity of economics, in its aspect as a science concerned with self-interest, to recognize and respond to only the immediate and tangible. Barbon makes this claim against Thomas Mun in particular, noting in the preface to A discourse of trade that Mun "doth better set forth the Rule to make an Accomplished Merchant, than how it may be most Profitable to the Nation" (Barbon 1905 [1690], 6).

Despite being concerned centrally with disciplining the new science of trade, Barbon's own thought represents perhaps the earliest casualty of the modern eclipse of political philosophy by economics. This eclipse, unwittingly wrought by Adam Smith and other figures of the Scottish Enlightenment (Cropsey 1975, 132), continues to conceal the early modern identification of economics with politics. Indeed, especially in the Anglo-American context, politics and economics constituted the central modern pairing in the science of the legislator (Smith 1979 [1776], IV. i). This eclipse, first for A discourse of trade and ultimately for major Enlightenment works, not least among them The wealth of nations, concealed the degree to which early modern economic arguments and analysis were profoundly informed, even bracketed, by larger political concerns.

In Barbon's case, the centrality of that larger political context to economic concerns initially revealed itself in the citational structure of his A discourse of trade. Barbon's treatment of trade began with a pointed appraisal of Machiavelli and Livy and concluded with a 
quotation from Campanella. In each instance, the authoritative voice of political philosophy provided the larger legitimating context for the upstart ideas of economics. By placing his economic ideas within the larger tradition of Livy, Machiavelli, and Campanella, Nicholas Barbon presented economics as a component and completion of political theory, but never an alternative to that discipline.

Livy, and those Antient Writers, whose elevated Genius set them upon the Inquiries into the Causes of the Rise and Fall of Governments, have been very exact in describing several Forms of Military Discipline, but take no Notice of TRADE; and Machiavel [sic], a Modern Writer, and the best though he lived in a Government, where the Family of MEDICIS had advanced themselves to the Soveraignty by their Riches, acquired by Merchandizing, doth not mention TRADE, as any way interested in Affairs of State (Barbon 1905 [1690], 7).

This is an argument for evolution not revolution. Understanding the political significance of trade represents the new task, the last element of the still incomplete modern project of political theory. Barbon's economics, as a field of both enquiry and action, represented either a sub-set within politics and political theory or a previously unrecognized form of politics. Either way, Barbon's enterprise aimed at completing the study and practice of politics. It did not seek to replace it with a new and novel discipline and agenda.

Far from participating in the eclipse of politics by economics, Barbon pursued economic ideas and phenomena in order to better understand and act upon the politics of an increasingly commercial world system. Most significantly, Barbon approached economics from the perspective of politics. Barbon's political economy drew on and expanded the perspective of the "best" of political theorists, Machiavelli. At its most primordial, Barbon's A discourse of trade starts from the wisdom of Machiavelli's Romans, who understood that "time sweeps everything before it and can bring with it good as well as evil, evil as well as good" (1998 [1532], 13). Barbon considered Machiavelli and Livy's work incomplete. At the time of their composition, history had yet to sweep before it that most revolutionary and modern of things, for both good and evil: commerce. 


\section{THE BREAK WITH ANALOGICAL ECONOMICS}

Barbon wrote political theory for the emerging age of commerce. He sought to understand the moral, political, and economic changes that occur as a result of commerce's ever increasing sweep. At the outset of $A$ discourse of trade, Barbon suggests that the central significance of his discussion of trade relates to national power. As a result, and in a manner reminiscent of Machiavelli's method in The prince, Barbon begins by freeing political economy from the constraints of an intellectually and politically confining morality. In the first section of $A$ discourse of trade, Barbon asserts that the principles which inform the economic conduct of individuals are different from, even at odds with, the principles that inform the economic conduct of nations. He illustrates this claim by contrasting the annual expenditures of an individual and a state. In considering these two sets of expenditures, Barbon observes an almost perfect contrast in economic qualities. To Barbon, an individual's resources appear finite, demanding frugality. In contrast, a nation's resources seem infinite. When appraising the consequences for an individual and a state spending near to their total income in a single year, Barbon contends that only the individual courts ruin. That ruin, or its avoidance, rests on a fundamental difference in the character of their respective resources.

This sheweth a Mistake of Mr. Munn, in his Discourse of Trade, who commends Parsimony, Frugality, and Sumptuary Laws, as the means to make an Nation Rich; and uses and an Argument, from a Simile, supposing a Man to have $1000 \mathrm{l}$. per Annum, and $2000 \mathrm{l}$. in a Chest, and spends Yearly $1500 \mathrm{l}$. per Annum, he will in four Years time Waste his $2000 \mathrm{l}$. This is true, of a Person, but not of a Nation; because his Estate is Finite, but the Stock of a Nation Infinite, and never can be consumed. For What is Infinite, can neither receive addition by Parsimony, nor suffer Diminution, by Prodigality (Barbon 1905 [1690], 11).

There is scarcely a more essential distinction in kind than that between finite and infinite. Individual economy and national economy stand not only differently appraised, but seem to be defined by fundamentally different principles. More radically still, the change of scale and arena generates fundamentally different outcomes for the 
same behavior. In The prince, Machiavelli suggests only that social and political location colors how we evaluate the actions of an individual, especially a prince.

And I know that everyone will confess that it would be a very praiseworthy thing to find in a prince all of the above mentioned qualities that are held good. But because he cannot have them, nor wholly observe them, since human conditions do not permit it, it is necessary for him to be so prudent as to know how to avoid the infamy of those vices that would take his state from him and to be on guard against those that do not, if that is possible; but if one cannot, one can let them go on with less hesitation (1998 [1532], 62).

Barbon significantly radicalizes Machiavelli's position. For Machiavelli, the context of an action's occurrence and its ultimate consequence determine the range of appropriate action and its evaluation. Barbon expands Machiavelli's position, arguing that profligacy on the part of a prince is not only judged differently, it entails a different outcome by virtue of its performance by a prince. Appearance, appraisal and outcome are all changed by the relocation of economic activity from the domestic to the political arena.

Nowhere is the radical nature of Barbon's economic insights, and their implied political consequences, more clearly demonstrated than in his discussion of the aspect of infinity in national economies. In rejecting "parsimony, frugality and sumptuary laws" (Barbon 1905 [1690], 11), Barbon aims at opening up not only new opportunities, but new ways of thinking about economic phenomena. For Barbon, breaking with past errors opens up the political possibilities of commerce in a fashion that echoes Machiavelli's account of his relationship with Livy and the role he envisions for history in politics. In Discourses on Livy, Machiavelli contends:

Nonetheless, in ordering republics, maintaining states, governing kingdoms, ordering the military and administering war, judging subjects, and increasing empire, neither prince nor republic may be found that has recourse to the example of the ancients [...]. Wishing therefore to turn men from this error, I have judged it necessary to write on all those books of Titus Livy that have not been intercepted by the malignity of the times whatever I shall judge necessary for their greater understanding, according to knowledge of ancient and 
modern things, so that those who read these statements of mine can more easily draw from them that utility for which one should seek knowledge of histories (Machiavelli 1996 [1517], Preface).

A discourse of trade echoes Machiavelli's expansion of political theory in Discourses on Livy. Like Machiavelli's political recovery of history, Barbon's economics provides new insights into the fuller nature of the political. Barbon values this new field of inquiry for quintessentially Machiavellian reasons. He pursues economics because of "that utility for which one should seek knowledge", the service of the state (Barbon 1905 [1690], 11). Barbon's insights about the curious character of national accounts matter as much for politics and the avenues of inquiry they open, as for the material realities they reveal. A discourse of trade possesses a larger purpose than disproving the confining economic moralism of Thomas Mun; it entails adding economics to the Machiavellian account of politics. ${ }^{2}$

\section{THE CONTOURS OF THE POLITICAL AND THE CHARACTER OF INFINITY}

Barbon's argument for economic infinity seeks to demonstrate two things. First, it aims to demonstrate the unique qualities of national economics freed from the assumptions of the individual/state analogy. More subtly, it aims to show the relevance of economics per se to what Adam Smith will eventually describe as the science of the legislator. Turning to the first of these tasks, Barbon sets aside the occluding lens of Mun's economic moralism to consider the economy as it actually is. Considering the argument for infinity, Barbon claims that common experience validates what appears to be an extraordinary claim. A discourse of trade reveals the economy's infinite aspect in agriculture and the productive cycle of the seasons. According to Barbon, the infinite emerges in agriculture's apparently endless capacity for

\footnotetext{
${ }^{2}$ Barbon treated the limits of this analogy in a more explicitly political fashion in his earlier Apology for the builder (1859 [1685]). Once again relying on Machiavelli to illustrate the connection between his economic and political ideas, Barbon wrote: "And if those gentlemen that fancy the city to be the head of the nation, would but fancy it like the heart, they would never be afraid of its growing too big; for I never read of such a disease, that the heart was too big for the body. And if we are of Machiavel's [sic] opinion, this simile is the best, for he saith, that citizens make no good counselors, for having raised their fortunes by parsimony and industry, they are usually too severe in punishing of vice and too niggardly in rewarding virtue" (Barbon 1859 [1685], 22).
} 
regeneration. Every year the economy harvests and sells the vast majority of its product, retaining almost nothing for the next year save seed. In the following year all is completely replaced and often expanded. As Barbon observes:

The Native Staple of each Country is the Riches of the Country, and is perpetual, and never to be consumed; Beasts of the Earth, Fowls of the Air, and Fishes of the Sea, Naturally Increase: There is Every Year a New Spring and Autumn, which produceth a New Stock of Plants and Fruits. And the Minerals of the Earth are Unexhaustable (Barbon 1905 [1690], 10).

While the notion that the earth's mineral resources are infinite may jar the modern ear, ${ }^{3}$ the principle of infinity as endless replenishment, for agricultural production at least, appeared obvious to Barbon. ${ }^{4}$ Tellingly, in the next paragraph Barbon expands his original account of England's economy to consider the particular products of neighboring nations and the relative advantages and disadvantages provided by these products and their trade. In this comparison, Barbon subtly begins to re-conceptualize previous views concerning the national economy. He sees the possibilities that these insights create in the explicit light of national disputes and contests. For Barbon, the state that recognizes the peculiar qualities of a nation's "native staple", especially its infinite aspect, stands positioned to benefit in ways far beyond the simply economic.

Barbon continued his study of the infinite nature of national economy and the advantage realized in its recognition, by discussing commerce's capacity to accommodate, with minimal dislocation, a steady increase in demand. To make his case Barbon cited the Doomsday book's census numbers. To Barbon, the Doomsday data suggested that the population of England had doubled since the time of William the Conqueror (Barbon 1905 [1690], 25). ${ }^{5}$ He observed that,

\footnotetext{
${ }^{3}$ For a fascinating treatment of Barbon's claim about minerals and seventeenth century ideas regarding their replenishment, see Finklestein 2000, 94.

${ }^{4}$ Barbon's description, in its sense of wonder at the emerging economy's potential, echoes in tone and broad substance, if not specifics, John Locke's (1988 [1689]) account of the productivity of agriculture in his Second treatise of government, II. 37. ${ }^{5}$ In his first treatment of the question of population growth, in An apology for the builder, Barbon drew on the analysis of the Doomsday book as presented by Matthew Hale in his Origination of mankind (1677) to argue for population growth but equally
} 
unlike a household whose denizens double in number, England seems neither strained nor strapped by its enlargement. Drawing on earlier work by John Graunt and William Petty, work assessed explicitly in Barbon's earlier essay An apology for the builder, he noted that far from ruin the doubling of the national number appeared to have made England wealthier (Appleby 1978, 165). Indeed, in an opposition that possesses further Machiavellian intimations, Barbon noted that what constitutes a burden for a single home represents a boon for an entire economy. In both questions of account, Barbon demonstrated that the analogy of personal and national wealth, with all its ethical and political baggage, is false. Freed of the confines of analogical reasoning, the state can consider the almost inestimable potential of the economy's expansive capacities.

\section{NEW SOURCES OF NATIONAL POWER}

Barbon immediately linked the new thinking about national revenue, its nature and the sources of its increase, to the circumstances of England and its neighbors. In this application and despite its enormous economic impact, Barbon indicated that the primary reason for rejecting the individual/state analogy was political not economic. However, to accomplish that political end Barbon needed to set aside at least two more errors concerning the nature of national revenue, one political and one economic. In economics Barbon redefined the sources of a nation's wealth almost eighty years before David Hume made this position famous in his essay "Of commerce" (Hume 1985 [1752]). Rather than bullion or land, Barbon argued that the true source of a nation's wealth was its citizens. In A discourse of trade, Barbon stated unequivocally "people are the riches and the strength of the country" (Barbon 1905 [1690], 29). Barbon's assertion, as with so much in the rest of the text, contains not merely an economic assertion but an equally important, albeit implied, political argument. This apparently simple statement, in its pairing of riches and strength suggests that the rise of the modern

for population migrations within England (1859 [1685], 9). Unlike A discourse of trade, in An apology, Barbon also explicitly acknowledges a debt to William Petty (Barbon 1859 [1685], 20) who had argued in his A treatise of taxes and contributions that "Fewness of People" was a burden not a benefit to government in the performance of its duties (Petty 1899, 21). 
market transformed the sources of national strength and the purpose of conquest. This claim-contained within a discussion of imperial projects-provided Barbon with grounds for the revolutionary claims to follow, most especially a fundamental reassessment of the character of trade. Barbon acknowledged as much when he declared:

[...] for until TRADE became necessary to provide Weapons of War, it was always thought prejudicial to the Growth of Empire, as too much softening the People by Ease and Luxury, which made their Bodies unfit to Endure the Labour and Hardships of War (Barbon 1905 [1690], 6).

In a subtle working out of the claim concerning the commercial character of the people in the discussion of empire that follows, Barbon presented a near complete rejection of the claim that trade is prejudicial to empire. Indeed, the account that follows asserts that trade comprises the new means to empire. In characterizing the people as the "riches and the strength" of a country, Barbon presented commerce as the uniquely modern source of national power.

Barbon acknowledged the breadth of consequence attached to his reassessment of the relationship between economics and politics. He recognized that the new commercial conception of the people's strength entailed the reordering of the relationship between martial and merchant virtues. Indeed, it entailed a reconsideration of the essential character of civic virtue. Barbon's account, in its most basic assumptions about virtue, shares the same ethical ground as Machiavelli's The prince and Discourses on Livy. The definitions of the good and the interests of the state overlap. However, here the sympathy ends. Barbon's essential innovation consists in a complete inversion of the early modern account of the relationship between self-interested citizens and professional armies (Smith 1979 [1776], V. 1.39). Sidestepping entirely the problematic relationship between wealth and virtue, Barbon argued that it is not selfinterested citizens who need modern armies and state apparati, but rather it is the modern state and its army that need self-interested citizens. Trade rapidly revolutionizes the political and social elements, population, prosperity, and urbanization, which initially prompted its ascension. In making this argument, Barbon began to reveal the ways in which his new political theory for a commercial age involved not merely 
completing Machiavelli and Livy, but, in important respects, displacing elements of their argument, especially their arguments concerning empire. In the Discourses on Livy Machiavelli writes:

I say therefore that not gold, as the common opinion cries out, but good soldiers are the sinew of war; for gold is not sufficient to find good soldiers but good soldiers are quite sufficient to find gold (Machiavelli 1996 [1517], II. x. 2).

Machiavelli understood that money was necessary for war; Barbon countered that ultimately money, or more precisely commerce, could achieve the same political ends as war. The preface to A discourse of trade declares: "Trade is now as necessary to Preserve Governments, as it is useful to make them Rich" (Barbon 1905 [1690], 5).

Barbon renders his case in at least two rhetorical registers. First he demonstrates in a resigned tone the truth of his central insight, that a citizen's riches and not their virtue are the new sources of national power. An apparently unwilling revolutionary, Barbon calls for a transformation in the citizens and state of England necessitated by realities on the continent. Turning to France, Barbon looks beyond traditional condemnations of ancient regime extravagance to the economic and ultimately political consequences of that literally sumptuous social order. He argues unequivocally that the Bourbon rejection of sumptuary laws and the embrace of luxury explain the rise of French power.

It is from Fashion in Cloaths, and Living in cities, That the King of France's Revenues is so great, by which he is become troublesome to his Neighbours, and will always be so, while he can preserve Peace within his own Country; by which, those Fountains of Riches, may run Interrupted into his Exchequer (Barbon 1905 [1690], 34).

Barbon does not mince words. The urban vices, in particular fashion in its essential inconstancy, sustain the fountain of riches that promises the Bourbon monarchs a global empire. Indeed, Barbon suggests, a conspiracy of frugality on the part of the rich would so impoverish the public coffers as to be "as dangerous to a Trading State as a Forreign War” (Barbon 1905 [1690], 32). 
Barbon then investigates the charges that the political makes against the economic: that it softens, it feminizes, and it enervates. Considering these factors, Barbon restates and expands his critique of the individual/state analogy. He notes that as with profligacy, the consequences of luxury differ for states as opposed to citizens. In the Bourbon example the citizenry is indeed weakened by the ephemera it pursues but, in a moment of economic and political alchemy, that pursuit translates upward into an all-too-real political strength. Barbon completed the political account of this new reality by identifying the Sun King's exchequer, and not his generals, as the new source of strength for France and concern for its neighbors. For England, the rise of commercial power in France imposes a new reality. The new politics of commerce does not merely bankroll political power, in its transactions it is political power. England must escape the old thinking, about frugality, sumptuary laws and the ambiguous relationship between wealth and virtue or perish.

Barbon's $A$ discourse of trade examines the series of revolutionary breaks that the market makes with existing assumptions concerning morality and politics. In breaking with the laws of nature and finitude and transforming the relationship between luxury and power, Barbon charted the growing disconnect between morality and economy. By discrediting the analogical relationship between the citizen spendthrift and the profligate state, Barbon deepened the moral break between macro and micro in politics begun by Machiavelli. Finally, in replacing the soldier with the merchant and the general with the exchequer, Barbon pointed to the new centers and sources of political power. Barbon's political examination of the market completed the inquiry begun by Machiavelli. Barbon's application of those insights to politics sought to complete Machiavelli's reordering of the political and moral horizons of the emerging modern world.

\section{THE NEW POLITICS OF COMMERCE}

In writing $A$ discourse of trade, Barbon set out to transform the most basic assumptions about the nexus of politics, economics and morality. In the opening sections, Barbon subtly moved economics out from under domestic ethical and moral assumptions and analogies and into 
the realm of the political. More explicitly, as his introduction indicates, he moved economics into the realm of the political as understood by Machiavelli. The second half of A discourse of trade, in treating trade between nations and trade within empires, aimed to transform the Machiavellian politics it so recently extended.

Matching the rhetorical structure of so much that follows, Barbon began $A$ discourse of trade by marveling at the capacity of trade to overcome traditional expectations and limitations. In particular, he wondered at the capacity of trade to escape the assumptions concerning scale and strength that informed European politics. As the introduction indicates, the unexpected escape from the politics of scale appeared most dramatically in the rise of the United Provinces and Venice, small states made great by commerce.

The Greatness and Riches of the United Provinces, and states of Venice, Consider'd with the little Tract of Ground that belongs to either of their Territory, sufficiently Demonstrate the great Advantage and Profit that Trade brings to a Nation (Barbon 1905 [1690], 5).

Reiterating the earlier equation of "strength and riches", Barbon connected two terms, one political and one economic, to suggest a new relationship between the two. Advantage, as applied to Venice and the United Provinces, appears to be defined by benefits generated by, but hardly restricted to, trade. In their rise, these two states express the missing element of Machiavelli's political theory, namely the overlooked political potential of trade. Venice and the United Provinces, which both demonstrated an inverse relationship between size and power, suggested that the development of international commerce, as opposed to simple conquest, represents the modern route to power. In considering this emerging modern mode, Barbon continued the rhetorical strategy begun with his account of the rise of commerce more generally. His argument for commercial empire combines both responsive and innovative elements. First, Barbon argued that commerce has so transformed the world that the traditional routes to empire have closed. Second, he explored the possibility that these transformations facilitate a new and novel form of empire, one uniquely suited to English circumstances. 
Making the case from necessity, Barbon returned to his economic analysis concerning the growth of the population of England and extended his examination to the continent. Considering the new political and economic realities of Europe, Barbon suggested that population growth is both a response to and eventually an engine for the broad productive potential of commerce (Barbon 1905 [1690], 31). He also revealed the new restrictions population growth presents to traditional modes of extending political power. He declared "There is now no room, the world is so full of people” (Barbon 1905 [1690], 29). Barbon's Europe had outgrown the old modes of military conquest. Armies, penned in and limited by ever-larger cities, could no longer hope to establish anything like the ancient empires of Alexander and Caesar. On the cramped continent, the military was unable to displace peoples or to so capture and subdue populations as to preclude assistance from nearby neighbors (Barbon 1905 [1690], 29). Moreover, on an ethical note, Barbon admitted that the density and sophistication of populations meant that their dominion, in the fashion of the ancient empires at least, would require barbarism too terrible to contemplate. Finally, as Barbon had already argued, if it is the people that constitute the wealth of a country, then the ancient modes of conquest invariably entail squandering the object of empire.

For the same Reasons, That the World is grown more Populous, That the Arts of War are more known. That the People of Europe live under a Free Government. It is as difficult to keep a Country in Subjection, as to Conquer it. The People are too Numerous to be kept in Obedience: To destroy the greatest Part, were too Bloody, and Inhuman; To Burn the Towns, and Villages, and so force the People to remove, Is to lose the greatest share in Conquest (Barbon 1905 [1690], 29).

This is a uniquely post-Machiavellian argument. The critique of empire-building, or rather traditional empire-building, is not moral but practical. The ambition may be sound, natural or inevitable, but the avenue is closed. More importantly, the same agent that closed the avenue will open a new route for the modern prince: commerce. Once again, Barbon found the example of the United Provinces instructive. 
Confronted with the ambitions of Europe's traditional empire builders, Spain and France, commerce permits the much smaller state to resist.

And Amsterdam, that was not long since, a poor Fisher-Town, is now one of the Chief cities in Europe; and within the same Compass of Time, that the Spaniard \& French have been endeavouring to Raise an Universal Empire upon the Land; they risen to that Height, as to be an equal Match for either of them at Sea (Barbon 1905 [1690], 30).

According to Barbon, only the preoccupying power of France and Spain prevent the United Provinces from becoming a new, distinctly commercial empire. England, spared from the continent by the Channel and already a naval power, stands positioned to become the next great empire, a commercial empire, necessarily borne upon the seas, the last open spaces in the age of commerce.

The end of old modes of extending power and influence, especially on the European continent, forced open new avenues of prosperity and power for Barbon's England. Barbon focused on these new avenues, but also the new relationship between prosperity and power. In delineating this new relationship, Barbon marked out the signal qualities of the nascent British Empire. His account even seems to hint at the not yet seen forms of commercial empire of the more distant future, the "voluntary empires" (Kagan 2009, 21) of NAFTA and the EU that inform much of modern international relations. Barbon recognized that such an empire, in accessing new means to imperial expansion, demanded new modes of imperial occupation. In order to succeed, imperial occupation could no longer rely on the practices of imperial tribute, tariff and appropriation that constituted the economic practices of previous empires. To succeed, the emerging commercial empires must be founded on the key insights about politics and economics that Barbon identified.

Barbon's international project begins with an application of the basic economic principles he first located within the domestic economy. Examining the sources of prosperity, Barbon identified the curious and perhaps counter-intuitive relationship between the rich and poor. In market societies, Barbon contended that: "The Chief Causes that Promote Trade, (Not to mention Good Government, Peace, and Scituation, and with other Advantages) are Industry in the Poor, 
and Liberality in the Rich" (Barbon 1905 [1690], 31). ${ }^{6}$ Note that once again, the causes that promote trade bring with them other, explicitly political benefits. In his discussion of empire, Barbon recommended this morally suspect but mutually beneficial relationship as the framework for the new commercial core and colonies.

In instituting this arrangement a commercial empire radically inverts the assumptions about national advantage and the flow of people and products that undergirded ancient empires. Instead of conquest and seizure, Barbon maintained that the successful modern empire should seek to improve the material conditions of its colonies, founding and drawing people to cities as market centers. The empire's new subjects, like England's industrious poor, should benefit from the liberality of the imperial center. Commerce (and not justice) requires this new mutuality.

The new empires, forced to look overseas by the crowding of Europe, must adopt novel modes of influence over newly acquired populations. Commercial realities, if not necessarily requiring an empire by invitation, nonetheless permit only an imperial rationale that differs dramatically from conquest-based incarnations. Indeed, it quickly becomes clear that while there may be an initial moment of conquest, the exigencies of the new imperial form preclude traditional forms of subjection.

The ways of preserving conquests gain'd by Sea, are different from those at Land. By the one, the Cities, Towns and Villages are burnt, to thin the People, that they may be the easier Governed, and kept into Subjection; by the other, the cities must be inlarged, and New ones built; Instead of Banishing the People, they must be continued in their Possession, or invited to the Seat of Empire; by the one, the Inhabitants are inslaved, by the other they are made Free (Barbon 1905 [1690], 30).

Barbon concluded by revealing the ultimate consequence of his declaration that people are the "strength and riches" of the nation. The nature of power in a commercial age leads inevitably to a radical

\footnotetext{
${ }^{6}$ Compare with Machiavelli: "For in every city these two diverse humors are found, which arises from this; that the people desire neither to be commanded or oppressed by the great, and the great desire to command and oppress the people. From these two diverse appetites one of three effects occurs in cities: principality or liberty or license" (Machiavelli, 1985 [1532], 39).
} 
and prescient reappraisal of the relationship between the center and colonies. The strength that emerges from the profit of trade and that extends the scope of the nation's economic power and influence can do so only by easing the scope of its political interventions. As Barbon's argument develops, it becomes increasingly clear that the non-economic benefits that commerce brings with it are not collateral benefits, but necessary conditions for trade to thrive. The commercial empire must be an empire of liberty.

More radically still, the freedom founded upon economic necessity entails foregoing traditional assumptions about inequality and primacy between the center and colonies. Barbon's argument highlights a commitment to rough equality between center and colony in moving from a discussion of that equality to a recommendation that the center, England, open its frontiers to the most successful citizens of its new commercial colonies. This opening of frontiers, justified by economic considerations, nonetheless promotes an expansive understanding of equality. Aware of the political and cultural ramifications of his argument, Barbon writes with great rhetorical subtlety, further blending the economic with the political while drawing out the final consequences of his equation of riches with strength. He begins his argument with a heavy-handed gesture to prevailing prejudice when he declares that the English are suited for commercial empire by a climate that renders citizens, game-cocks, and mastiffs "nowhere else so stout" (Barbon 1905 [1690], 31). However, in his actual recommendations, the language of stock and soil disappears entirely. Passing his arguments for equality and liberty through the reassuring framework of a treatment of the promotion of trade, Barbon suggests:

And were there an Act for a General Naturalization, that all Forreigners, purchasing Land in England, might Enjoy the Freedom of Englishmen, It might within much less Compass of Time, than any Government by Arms at Land, arrive to such a Dominion: For since, in some Parts of Europe, Mankind is harrassed and disturbed with Wars; Since, some Governours have incroached upon the Rights of their Subjects, and inslaved them; Since the People of England enjoy the Largest Freedoms, and Best Government in the World; and since by Navigation and Letters, there is a great Commerce, and a General Acquaintance among Mankind, by which the Laws and the Liberties of all Nations, are known; those that are oppressed and inslaved, 
may probably Remove, and become the Subjects of England (Barbon 1905 [1690], 31).

Barbon's endorsement of centripetal migration represents the final and fullest elucidation of the political and imperial consequences of the commercial transformation of politics. If the people constitute the economic and political power of an empire then those people, and not their produce, constitute the resource most in need of extraction from the colonies.

Commerce provides the means and rationale for a novel form of empire, but also implicitly suggests a new remedy for one of the oldest dilemmas of empire. Every empire eventually encounters the problematic relationship between claims of autochthonic privilege and the demands of long subjected populations. Each empire aims to solve this problem in its own way. ${ }^{7}$ Barbon's commercial account points to a uniquely modern solution. The modern commercial empire, associating its citizens' strength with their riches, stands upon a perfectly transferable vision of civic value if not virtue. The commercial conception of the citizen as wealth creator detaches the individual's status from claims to shared history, common culture or original possession. Citizenship emerges out of economic transactions, the immediacy of commercial self-interest that entirely avoids the fraught territory of blood and soil. Commerce provides for a new imperial expansion that empowers the state at its frontiers and eases the absorption of the most vital colonial resource at its center.

Yet, Barbon's argument goes farther still than the commercial reframing of citizens and civic virtue. Barbon's new view of naturalization amounts to a restatement of his earlier account of commerce's effect on Europe. Facilitated by commerce, the trade routes, the intensification of population density and the increased ease of communication, all mean that English liberty is better known abroad. Commerce provides the pathways for a political appeal. Those seeking freedom and prosperity head for England, either from the colonies commerce built or from the countries that commerce has made aware of English liberty. As a result, England fills with the strength and riches

\footnotetext{
${ }^{7}$ For the Ciceronian treatment of this dilemma see my "The rise of global power and the music of the spheres" (Kellow 2009).
} 
precipitated by the inflow of people. Here again, the political ends up being both complemented and transformed by the economic. The inflow of people to England empowers but, at the same time, transforms the substance of the nation. The commercial empire's external modes redefine its internal essence. ${ }^{8}$ A commercial empire, built by mutual benefit and sure in its liberty empowers the economy to access people, the primary sources of riches and ultimately, strength.

\section{CONCLUSION}

Barbon's rhetoric of the new politics of commerce moves ineluctably from revelation to resignation and ultimately to revolution. The essay begins with Machiavelli and Livy, whose vision, lacking an account of trade, remains incomplete. A discourse of trade emancipates economics from the confines of morality, most captivatingly incarnated in the individual/state analogy.

Barbon then illuminates the new politics in tones of resignation, inevitability, and necessity. In the discussion of trade, especially international trade, Barbon's tone changes; the emerging world of markets may not be of our choosing, but the political advantage to be taken from it can be. Finally, in discussing commercial empire Barbon returns to political theory and conspicuously to the language of economic and political liberty. Just as his essay begins with Renaissance meditations on power, so too does it end. A discourse of trade concludes with Campanella, writing "an hundred years since" (Barbon 1905 [1690], 42). Barbon turns back to political theory and sees Campanella warning of the same Gallic threat he identifies.

Campinella [sic], who Wrote an 100 years since, upon considering of the Great Tract of the Land of France; says, That if ever it were United under one Prince, it would produce so great a revenue; It might give Law to all Europe (Barbon 1905 [1690], 42).

In its specifics, Campanella's claim provides a curious coda to A discourse of trade. Throughout the essay, Barbon claims as his central insight a new account of the relationship of prosperity to power. Now, in the concluding passages, Barbon presents Campanella offering a version

\footnotetext{
${ }^{8}$ Consider Aristotle's Politics (1996, 30-40).
} 
of the argument that he has been making all along. In fact the passage from Campanella's Hispania Monarchia represents a dual reprise. First, it relocates Barbon within the tradition of political theory, second Barbon places his enterprise and its concerns alongside Campanella's. In doing so, Barbon announces his return to the political theory fold, having completed the work begun by Machiavelli and Livy.

Campanella also serves, by way of Barbon's return to political theory, to restate the risks posed by France. Campanella legitimates not just Barbon's enterprise but his threat analysis. Barbon and Campanella agree that commercial revenues represent the key to French power. Barbon offers the English alternative, a new politics of commerce that is fundamentally free. Barbon ends A discourse of trade with Campanella, with political theory, but with a political theory that faces not merely a new reality, the politics of commerce, but a new question, what sort of politics of commerce? What sort of commercial state should provide the emerging market world with its new universal law? In ending with the conflict and contrast between the French and English states, Barbon restates the rhetoric of resignation and revolution that informs A discourse of trade as a whole. In placing the perennial Anglo-Gallic contest at the conclusion of his analysis of trade, restating it through Campanella's assessment of Bourbon power, Barbon forcefully locates his economic ideas within the context of a newly expanded political theory.

Ultimately, Nicholas Barbon's A discourse of trade presents, in its construction, substance and rhetoric, an early outline of a new science of the legislator for the new politics of commerce. Nearly a century later Adam Smith famously argued that political economy was "a branch of the science of a statesman or legislator" (Smith 1979 [1776], IV. i. 1). By then, the urgency of placing economics within the context of political theory was slowly, ineluctably, giving way to a new urgency, to retain for political theory a place within economics. The sense of rank and priority between disciplines had changed. Nonetheless, Barbon's central insight endures, Barbon's account of trade is an account of politics, his account of politics is an account of trade. Barbon's economics and politics are inextricably linked and mutually informing, the comprehension of one requires the comprehension of the other. 


\section{REFERENCES}

Appleby, Joyce. 1978. Economic thought and ideology in seventeenth century England. Princeton: Princeton University Press.

Aristotle. 1996. The politics and the constitution of Athens. Trans. Stephen Everson. Cambridge: Cambridge University Press.

Barbon, Nicholas. 1905 [1690]. A discourse of trade. Baltimore: Johns Hopkins Press.

Barbon, Nicholas. 1971 [1696]. A discourse concerning coining the new money lighter: in answer to Mr. Lock's considerations about raising the value of money. Westmead (UK): Gregg International Publishers.

Barbon, Nicholas. 1859 [1685]. An apology for the builder; or a discourse shewing the cause and effects of the increase of building. In A select collection of scarce and valuable economical tracts, ed. John R. McCulloch. London: Lord Overstone, 1-26.

Berry, Christopher. 1994. The idea of luxury. Cambridge: Cambridge University Press.

Clark, Henry C. 2003. Commerce, culture, and liberty. Indianapolis: Liberty Fund.

Cropsey, Joseph. 1975. Adam Smith and political philosophy. In Essays on Adam Smith, eds. Andrew S. Skinner, and Thomas Wilson. Oxford: Clarendon Press, 132-153.

Finklestein, Andrea. 2000. Nicholas Barbon and the quality of infinity. History of Political Economy, 32 (1): 83-103.

Hale, Matthew. 1677. The primitive origination of mankind, considered and examined according to the light of nature. London: William Godbid for William Shrowsbery.

Hume, David. 1985 [1752]. Political discourses. In Essays moral, political and literary, ed. Eugene F. Miller. Indianapolis: Liberty Fund, part II.

Kagan, Robert. 2009. The return of history and the end of dreams. New York: Random House.

Kellow, Geoffrey C. 2009. The rise of global power and the music of the spheres: philosophy and history in Cicero's De Re Publica. In Enduring empire: ancient lessons for global politics, eds. T. Koivokoski, and D. Tabachnick. Toronto: University of Toronto Press, 145-160.

Locke, John. 1988 [1689]. Two treatises of government. Ed. Peter Laslett. Cambridge: Cambridge University Press.

Machiavelli, Niccolo. 1996 [1517]. Discourses on the first decade of Titus Livy. Trans. Harvey C. Mansfield, and Nathan Tarcov. Chicago: University of Chicago Press.

Machiavelli, Niccolo. 1998 [1532]. The prince. Trans. Harvey C. Mansfield. Chicago: University of Chicago Press.

Petty, William. 1899. The economic writings of Sir William Petty, vol. I. Cambridge: Cambridge University.

Schumpeter, Joseph. 1954. History of economic analysis. New York: Oxford University Press.

Smith, Adam. 1979 [1776]. An inquiry into the nature and causes of the wealth of nations, ed. R. H. Cambell, and A. S. Skinner. Indianapolis: Liberty Fund.

Ullmer, James. 2007. The macroeconomic thought of Nicholas Barbon. Journal of the History of Economic Thought, 29 (1): 101-116.

Vickers, Douglas. 1959. Studies in the theory of money, 1690-1776. New York: Chilton Company Publishers. 
Geoffrey C. Kellow is assistant professor at The College of the Humanities, Carleton University (Ottawa, Canada). He teaches intellectual history, with a particular focus on Adam Smith and earlier Anglo-American accounts of the free market. His current research examines the conjunction of commerce and civic education in the philosophy of Adam Smith.

Contact e-mail: <Geoffrey_Kellow@carleton.ca> 